\title{
Proses Pendidikan Sumber Kerangka Perpaduan dan Pembinaan Moral Jati Diri Bangsa dalam Konteks Penganalisisan Sosio Politik
}

\author{
The Education Process as a Root for the Unity Framework and the Moral Construction of \\ the National Identity in the Context of Socio-Political Analyzing
}

\author{
Kamarudin Musa ${ }^{\mathrm{a}}$, Norizan Saad ${ }^{\mathrm{b}}$, Ibrahim Tamby Chek $^{\mathrm{c}}$, Maryam Mahdinezhad ${ }^{\mathrm{d}}$ \\ ${ }^{a-d}$ Universiti Pendidikan Sultan Idris, Malaysia, kamarudin@fpe.upsi.edu.my \\ norizan@fpe.upsi.edu.my,ibrahim@fpe.upsi.edu.my,maryam.m@fpe.upsi.edu.my
}

\begin{abstract}
Abstrak
Pendidikan merupakan penentu kepada pembangunan bangsa dan pembentukan kesatuan sosial. Penekanan kepada proses pendidikan yang berkait dengan kepentingan ideologi dan falsafah negara bangsa, merupakan hakikat yang sewajarnya dilakukan secara bermakna. Pemerkasaan proses pendidikan sewajarnya bersumberkan kepada semangat yang terkandung dalam Perlembagaan Negara. Perbincangan dilakukan secara konstruktif kontekstual berdasarkan pendekatan sosio-politik-historis dengan meneliti dokumen-dokumen yang menjadi sumber kepada pembentukan dan pelaksanaan dasar pendidikan negara, merangkumi Perlembagaan Negara, Akta Pendidikan 1996, Akta Pengajian Tinggi dan Akta Pendidikan Tinggi Swasta 1996 serta Akta Bahasa Kebangsaan 1967 dan dokumen-dokumen berkaitan dengan dasar sosial negara. Terdapat lima dimensi konstruk yang dijadikan pembolehubah kerangka analisis, iaitu; Pendidikan Vernakular pelbagai budaya, Kerangka dasar idenititi nasional, Bahasa Melayu dalam realiti pendidikan negara, Liberalisme bahasa pendidikan swasta dan Pendidikan pelebaran jurang perpaduan. Proses pendidikan mempunyai impak ke atas perpaduan dan pembinaan moral jati diri bangsa. Pembentukan dasar dan pelaksanaan dasar adalah untuk membentuk secara konstruktif inspirasi nasional, berhubung pemantapan jati diri bangsa. Adanya ketidakpatuhan, berpunca pertentangan di antara hasrat yang didokumen dengan proses politik. Proses pendidikan yang sepatutnya menjadi pemangkin kepada jati diri bangsa serta pengikat kesatuan sosial telah terdedah kepada unsur manipulasi politik yang menimbulkan pertelagahan sosial. Kesatuan ideologi serta keutuhan kesatuan sosial merupakan teras kepada pembinaan perpaduan serta kemantapan jati diri bangsa. Proses pendidikan seharusnya dilaksanakan dengan mengambil kira aspirasi yang tertulis dalam setiap dokumen yang dizahirkan sebagai kerangka pembentukan dan pelaksanaan dasar negara. Memungkiri keperluan yang diwujudkan, tentunya mempunyai implikasi terhadap usaha membentuk negara bangsa yang berdiri di atas landasan norma yang berpaksikan kekuatan akal budi serta keutuhan keperibadian.
\end{abstract}

Kata kunci: proses pendidikan, moral jati diri, kesatuan sosial, sekolah-sekolah vernakular, liberalisme bahasa

\begin{abstract}
Education is a critical factor in the development of the nation and the establishment of social unity. The education processes should be the meaningful element to cultivate the important of the philosophy and ideology of the nationstate. The empowerment of the education process should be based on the spirit contained in the Constitution of the State. Discussions done using contextual constructively method based on socio-political-history approaches by studying documents which are identified as the sources of the formation and implementation of national education policies, encompassing the National Constitution, Education Act 1996, Higher Education Act and Private Higher Education Act 1996 and the National Language Act 1967 and documents related to the country's social policy. There are five dimensions of construct was used as analytical framework variables; Multicultural Vernacular education, national identity framework policy, Malay language in national education reality, Liberalism of private education language and Extension of education unity gap. The educational process has an impact on national unity and moral development. The creating policies and the implementation policies, no doubted was the action taken to strengthen the national inspirations, ideally called national identity. The existence of non-compliance, arising from the discrepancies between which has been documented and the struggling among
\end{abstract}


the politician interest, which be unrest to the mind of the people, that created social conflict. The education process should be the catalyst for national identity and social unity. The unity of ideology and the integrity of social unity is the core foundation of national unity and stability. The education process should be implemented by taking account to all the written aspirations document which is classified as a root for the establishment of national policy framework. Denying the realities, of course, become the challenge in order to established the formation of nation-state which emerged with the strong element power of reason and the integrity of the personality.

Keywords: education process, moral identity, social unity, vernacular schools, language liberalism.

\section{PENDAHULUAN}

Asas kepada pembangunan dan pembinaan proses pendidikan seharusnya mengambil kira kandungan yang terdapat dalam dokumen pembentukan falsafah dan ideologi negara. Proses pendidikan harus mengambil kira akan semangat dan roh yang terkandung dalam Perlembagaan Negara yang merupakan dokumen asas kepada pembentukan dasar-dasar negara, khususnya dasar pendidikan sebagaimana yang dicerminkan di dalam Akta Pendidikan 1996, Akta Pendidikan Tinggi Swasta 1996 dan juga dasar-dasar sosial negara.

Kerangka identiti kemalaysiaan itu, hakikatnya telah tertera dalam konteks kandungan perlembagaan negara. Proses pendidikan seharusnya dirangka dalam konteks keperluan yang selari dengan kehendak tertulis dalam Perlembagaan Negara kerana ia merupakan acuan dalam konteks pembinaan negara serta penentu haluan tingkah laku rakyat dalam membentuk struktur dan sistem sosial.

Perkara-perkara yang berkaitan pembinaan negara bangsa perlu menjadi perhitungan utama dalam pelaksanaan proses pendidikan, ini dinyatakan dengan jelas dalam intisari perlembagaan negara, Perkara 1, 3 dan 4, sewajarnya dijadikan petunjuk penting bagi menentu realiti sebenar bentuk pendidikan negara, memperjelaskan batas sempadan geopolitik, agama, negara dan prinsip sempadan perundangan negara. Perkara-perkara ini tentu menjadi penentu batas moral dalam membentuk tingkah laku dan sikap individu terhadap negara.

\section{KERANGKA LANDASAN PEMIKIRAN}

Proses pendidikan merupakan aspek yang paling penting dalam menentukan kekuatan kesatuan bangsa, khususnya dalam kerangka membentuk keterikatan terhadap nilai perpaduan serta pembangunan aspirasi negara. Pendidikan, sebagaimana ditegaskan dalam Penyata Razak (1956), merupakan mekanisme yang terpenting dalam usaha untuk mewujudkan perpaduan serta identiti nasional bagi negara Malaysia.

Aspirasi ini dipertegaskan kemudiannnya melalui Laporan Jawatan Kuasa Kabinet Mengkaji Pelaksanaan Dasar Pelajaran (1979). Matlamat ke arah membina masyarakat Malaysia yang mempunyai kekukuhan jati diri, serta kekuatan citra perpaduan ini juga dipertegaskan dalam Pelan Pembangunan Pendidikan Malaysia 2013-2015.

Pemikiran berkaitan perpaduan dan pembinaan jati diri merupakan isu yang mendominasi pemikiran serta perspektif masyarakat Malaysia pasca merdeka. Pembentukan negara berasaskan unsur kemajmukan, berlatarkan kepelbagaian etnik dan subetnik, merupakan sesuatu yang sukar untuk dielakkan, berlandaskan reka bentuk yang sedia direncana British, 
sebagai kuasa penjajah, bertujuan untuk memeliharan kepentingan politik, sosial dan ekonomi mereka (Arshad, 2007; Kheng, 2007; David, McLellan, Meng, Le \& Ties; 2010).

Kepelbagaian yang wujud, khususnya dalam aspek sosio budaya telah menyebabkan wujudnya pembahagian sektor sosial dan kerencaman budaya yang tentunya membawa kepada wujud kepelbagaian tafsiran dalam konteks perhubungan sosial yang akan menjadi titik beza antara etnik. Situasi ini tentunya membawa kepada jurang kepentingan yang menyebabkan usaha ke arah pembinaan satu negara bangsa serta keseragaman pemikiran sosial akan berdepan dengan halangan yang besar (Kheng, 2007).

Pembinaan negara memerlukan satu bentuk jati diri yang dapat membina satu konsep bangsa yang berkongsi budaya, realiti ini amat penting dalam konteks pembicaraan struktur pembentukan masyarakat dan pelaksanaan proses pendidikan di Malaysia (David, McLellan, Meng, Le \& Ties; 2010). Hakikatnya, soal perpaduan dan jati diri rakyat Malaysia, merupakan sesuatu yang amat kompleks, memandangkan pembentukan masyarakat Malaysia adalah hasil daripada reka bentuk yang dilakukan kolonial dalam memenuhi keperluan ekonomi mereka.

Teras kepada pembentukan masyarakat lebih cenderung kepada mempertahan kewujudan identiti etnik secara kelompok, walhal realiti negara adalah terbina atas majoriti budaya serta persekitaran sosial kebumiputeraan. Secara khusus boleh dijelaskan bahawa pembentukan Malaysia didorong terhadap penerimaan kepelbagaian kaum, agama, budaya dan bahasa (Ismail Ibrahim, 2010).

Realiti kepelbagaian ini terbina secara berterusan, memandangkan sepanjang sejarah pembinaan masyarakat, proses politik tidak pernah mengarah kepada wujudnya pendekatan asimilasi dalam konteks menyerapkan sosio budaya etnik lain yang bersifat minoriti ke dalam kesatuan budaya mojoriti berteraskan kebumiputeraan (Kheng, 2007; Ismail Ibrahim, 2010).

Hakikatnya ini telah membentuk masyarakat Malaysia yang berpecah kepada sentimen kaum, meskipun berada dalam kesatuan geo-politik yang diperhalusi melalui peruntukan perlembagaan negara, namun secara umum masih tetap wujud konflik aspirasi antara etnik. Setiap etnik masih kukuh dan enggan berpisah dengan budaya, bahasa dan norma sosial masing-masing (Kheng, 2007; Ismail Ibrahim, 2010).

Meskipun beberapa dasar serta falsafah negara diwujudkan, seperti Dasar Pendidikan Kebangsaan, Dasar Perpaduan Negara, Dasar Kebudayaan Kebangsaan, Dasar ekonomi Baru dan juga penzahiran Rukun Negara, namun masih tetap menunjukkan unsur bagi menyatukan rakyat ke dalam satu kesatuan nilai bersama masih menjadi hambatan (Arshad, 2007). Apa yang jelas rakyat umumnya masih terbentuk dalam aliran pemikiran serta perspektif hidup yang masih berteraskan etnik, agak sukar untuk membentuk aliran pemikiran berteraskan merentasi kelompok etnik.

Reka bentuk masyarakat yang dirangka pihak kolonial masih menjadi pola dalam realiti struktur masyarakat. Meski pun demikian beberapa petunjuk dalam konteks masyarakat Malaysia pasca Dasar Ekonomi Baru dan Dasar Pembangunan Nasional, telah sedikit sebanyak telah mengubah bentuk hubungan dan penempatan masyarakat, namun struktur hubungan sosial masih juga berteraskan kekelompokan kaum (Embong, A.R, 2007). 
Unsur ke arah memperkukuhkan jati diri dengan berasaskan nilai, pemikiran serta aspirasi negara sebagaimana yang dinyatakan dalam Perlembagan Negara serta Dasar Kebudayaan Kebangsaan dan Dasar Pendidikan Negara masih menjadi bahan perdebatan.Berdasarkan kajian Arshad (2007), struktur dan pola masyarakat yang wujud sewaktu pengalaman kolonialisasi telah menjadi warisan kepada pembentukan masyarakat Malaysia pasca merdeka, berterusan kepada fasa pemodenanan negara yang ditandai dalam dekad-dekad 1980 an membawa kepada era abad ke 21.

Secara tidak langsung perkara ini mempengaruhi landskap pendidikan negara. Konsep pendidikan yang diperkenalkan pihak kolonial yang berteraskan keperluan etnik, nampaknya masih menjadi pilihan dalam konteks masyarakat Malaysia pasca pemodenan (Arshad, 2007; Othman at. al., 2012).

Meskipun Dasar Pendidikan Kebangsaan telah membentuk secara khusus ideologi pendidikan dengan penekanan terhadap usaha untuk mewujud perpaduan serta pengukuhan jati diri negara dengan menjadikan bahasa Kebangsaan sebagai bahasa penghantar utama dan menetapkan satu sistem pendidiakan yang seragam dalam aspek kurikulum, namun, sebagaimana kajian David (2010) dan Kheng (2007) dan Othman et. al., (2012) pemikiran yang dihasratkan oleh Dasar Pendidikan Negara ini, masih belum kukuh untuk membentuk satu nilai "kebangsaan" mutlak yang merentasi pegangan kaum. Hakikatnya Malaysia masih tetap wujud atas dasar kepelbagaian etnik dengan kerencaman bahasa, budaya, pemikiran, adat dan juga sudut pandangan.

Berdasarkan kepada hasrat pendidikan, melalui Penyata Razak 1956, Akta Pendidikan 1961, Laporan Kabinet dan Akta Pendidikan 1996, Laporan Kabinet 1979, Pelan Induk Pembangunan Pendidikan Malaysia 2006-2010 dan juga Pelan Pembangunan Pendidikan Malaysia 2013-2025 secara berterusan meletakkan agenda perpaduan dan pembentukan jati diri sebagai konteks kepada pelaksanaan proses pendidikan.

Berhubung dengan usaha untuk memperkukuhkan perpaduan dan jati diri rakyat Malaysia, mengiktiraf kedudukan dan kewujudan Sekolah-sekolah Jenis Kebangsaan Cina dan Tamil, serta dinukilkan bahawa sekolah jenis ini dibiayai sebahagiannya oleh Kementerian Pelajaran Malaysia dan dikira sebagai sekolah bantuan kerajaan, sukatan pelajaran dan gaji guru di Sekolah Jenis Kebangsaan dibiayai oleh kerajaan. Kurikulum sekolah ini dengan Sekolah Kebangsaan juga sama, yang berbeza ialah bahasa pengantar yang digunakan (Tan, 2010).

Pengiktirafan yang diberikan oleh Akta Pendidikan 1996 terhadap Sekolah-sekolah Jenis Kebangsaan Tamil dan Cina, ini merupakan satu kerangka dalam membentuk imej budaya dan identiti kebangsaan negara. Ini bermakna proses pendidikan meskipun wujud dalam kerangka unsur pemisahan lokasi serta budaya, namun dilihat dalam aspek tabii masyarakat Malaysia, maka ia dilihat dalam realiti kesatuan dalam kepelbagaian (Tan, 2010; Jamaludin, 2011).

Sungguhpun demikian dalam aspek yang lain, kewujudan pemisahan aliran pendidikan ini telah menyebabkan falsafah yang berbeza dalam aspek pembangunan matlamat pendidikan. Apa yang jelas kewujudan pendidikan Cina dan Tamil ini, secara tidak langsung lebih kepada usaha untuk memperkukuhkan budaya, bahasa dan pemikiran etnik Cina dan India terhadap realiti warisan nilai kehidupan tradisi mereka (Tan, 2010). 
Meskipun landasan proses pendidikan negara diasaskan kepada Akta Pendidikan Kebangsaan 1996 dan Akta Pendidikan Tinggi Swasta 1996, sudah tentu sewajarnya isu kepada pembentukan perpaduan dan pembinaan jati diri negara telah memenuhi satu standard yang membawa kepada tersebar dan terbentuknya unsur nilai yang mantap sebagai kerangka praktis perpaduan dan jati negara.

Pegangan dalam membentuk kerangka perpaduan dan jati diri negara telah dinyata secara mantap dalam kandungan Falsafah Pendidikan Kebangsaan dan dinukilkan dalam Rukun Negara. Ini bermakna asas kepada pembentukan perpaduan dan jati diri bangsa telah diperkejap secara tuntas dan dinyatakan secara berdokumen. Aspek nilai, moral, ideologi dan prinsip dalam pembinaan perpaduan serta pengukuhan jati diri bangsa telah dibangun dengan reka bentuk serta model yang agak paraktikal dan mempunyai teras yang kuat, kerana dilembagakan dalam Perlembagaan Negara (Arshad, 2007; Razak, 2009; Tan, 2010).

Sebagaimana yang ditegaskan Yusof (1985) dan Zubir (2012), dalam hal ini landasan yang paling penting, adalah meletakkan segala bentuk dokumentasi yang mendefinisi akan kerangka wajah generasi Malaysia, khususnya sebagaimana terzahir dalam Perlembagaan Negara sebagai rujukan mutlak dalam membentuk tingkah laku rakyat serta cerminan dan sumber dalam pembentukan setiap dasar negara.

Berdasarkan kepada realiti, proses pendidikan serta keperluaan bagi memperkukuh pendidikan sebagai paksi untuk menanam ideologi kesatuan matlamat, khususnya terhadap usaha untuk mewujudkan perpaduan dan jati diri bangsa, dalam diri generasi muda pelajar, maka fokus haruslah ditumpu kepada usaha untuk menganalisis dan menjelaskan beberapa sisi pembolehubah yang menjadi latar kepada asas kewujudan sosio budaya masyarakat Malaysia dan secara tidak langsung mempengaruhi pola pemikiran, tingkah laku serta persepsi masyarakat dalam konteks hubungan sosial antara etnik.

Perbincangan secara khusus berkaitan unsur-usnur pendidikan vernakular pelbagai budaya, kerangka dasar identiti nasional, bahasa Melayu dalam realiti pendidikan negara, liberalisme bahasa pendidikan swasta dan pendidikan pelebaran jurang perpaduan. Komponen pembolehubah ini merupakan aspek yang mendasari isu dalam konteks petunjuk kepada usaha untuk membentuk perpaduan dan memperkukuh jati negara.

Secara khusus komponen pembolehubah ini merupakan teras dasar yang dinyatakan secara tersirat mahu pun secara tersurat dalam dokumen utama negara iaitu Perlembagaan Negara dan juga Akta Pendidikan 1996. Tumpuan memperkemas dasar dan juga tindakan berlandaskan keperluan pembolehubah ini, menjadi anjakan kepada usaha memperkukuh perpaduan dan mempertingkat kesedaran mempertahan jati dir bangsa.

\section{PENDIDIKAN VERNAKULAR PELBAGAI BUDAYA}

Pendidikan satu aliran, sering kali dijadikan isu dan perbincangan oleh pelbagai pihak apabila mengulas situasi polarisasi kaum. Kesimpulan umum, terdapat pihak yang melihat secara sinikal dan skeptis dengan mempertikai akan rasional kewujudan sekolah-sekolah vernakular, sekolah vernakular Jenis Kebangsaan Cina dan Jenis Kebangsaan Tamil, dilihat sebagai unsur pengganggu dalam konteks perpaduan nasional. Namun hakikatnya, sekolah-sekolah 
vernakular ini telah pun wujud seawal negara mencapai kemerdekaan (Jadi, 1990; Arshad, 2007; Hussin, 2008; Tan, 2010)

Maka kewujudan sekolah-sekolah vernakular Cina dan Tamil, merupakan konsensus kemerdekaan antara kaum dalam proses untuk merealisasi sebuah negara bangsa, juga boleh dikatakan sebagai legasi yang ditinggalkan British, monumen dan artifak warisan tinggalan penjajahan British, satu warisan yang menjadi lambang kepada penciptaan masyarakat pelbagai budaya. Satu keunikan sosial yang seharusnya menjadi kekuatan dalam hubungan sosial dan pembangunan ekonomi serta sepatutnya menjadi kelebihan dan kekuatan dalam melonjak pemacuan daya saing negara (Jadi, 1990, Hussin, 2008).

Berdasarkan kepada latar kewujudan sekolah-sekolah jenis kebangsaan Cina dan Tamil, ia memperlihatkan sebagai tolak ansur dalam membentuk ekologi sosial, bagi membolehkan setiap etnik dan kaum mempunyai ikatan terhadap asas tradisi warisan masing-masing, realiti ini hakikatnya juga adalah selaras dengan nilai kemanusiaan dan tradisi pensejarahan.

Ini bermakna setiap etnik atau kaum, dalam konteks Malaysia terbentuk daripada jaluran bangsa yang berbeza, penerimaan hakikat ini merupakan satu pengiktirafan terhadap dinamika pembentukan masyarakat Malaysia dan merupakan satu keunikan sosial. Bagaimana pun ini bukan satu panghalang ke arah membentuk akal budi sosio budaya Malaysia (Othman, Sabil, \& Lateh, 2015)

Sekolah-sekolah vernakular ini, telah pun wujud dalam konteks status quo dan telah diiktiraf sebagai sebahagian daripada sistem pendidikan kebangsaan, sebagaimana yang dinyatakan dalam Akta Pendidikan 1996, dinyatakan dalam perkara 28, "Tertakluk kepada peruntukan Akta ini, Menteri boleh menubuhkan sekolah kebangsaan dan sekolah jenis kebangsaan dan hendaklah menyenggara sekolah-sekolah itu".

Berdasarkan definisi Akta Pendidikan 1996, sekolah jenis kebangsaan, diertikan sebagai sekolah rendah atau sekolah rendah bantuan kerajaan:

a. yang menyediakan pendidikan rendah yang sesuai bagi murid dari umur enam tahun.

b. yang menggunakan bahasa Cina atau Tamil sebagai bahasa pengantar utama; dan

c. yang menjadikan bahasa kebangsaan dan bahasa Inggeris sebagai mata pelajaran wajib.

Berdasarkan kepada peruntukan Akta Pendidikan 1996, maka kemunculan sekolah jenis kebangsaan ini, tertakluk sepenuh dibawah kuasa perundangan dan kawalan pihak kerajaan dalam aspek dasar, program, kawal selia peraturan dan juga pelaksanaan aktiviti. Bahkan Menteri mempunyai kuasa yang penuh ke atas sekolah-sekolah vernakular ini. Menteri mempunyai kuasa untuk menubuh, bermakna Menteri juga mempunyai kuasa untuk menutup.

Bermakna pelanggaran ke atas aspek perundangan secara serius, membolehkan Menteri menutup sekolah-sekolah vernakular. Persoalan berkaitan dengan jejasan terhadap perpaduan nasional, agak kurang tepat untuk dikaitkan dengan kewujudan sekolah-sekolah vernakular.

Tambahan pula, sekolah-sekolah vernakular ini hanya wujud pada peringkat rendah dan menggunakan kurikulum kebangsaan sebagaimana ditegaskan dalam Perkara 18 dan Perkara 130 Akta Pendidikan 1996, iaitu Peraturan-Peraturan Pendidikan (Kurikulum Kebangsaan) 1997 berkuat kuasa 1 Januari 1998. 
Sekolah-sekolah vernakular ini, meskipun wujud dalam lokaliti yang berbeza serta dimensi budaya yang berbeza, namun berdasarkan persekitaran kewujudannya dalam sebuah entiti geografi negara yang mempunyai asas ideologi yang kuat bersumberkan Perlembagaan Negara, dasar pendidikan yang dilandaskan kepada falsafah Akta Pendidikan 1996, di samping wujudnya ikatan kesatuan pemikiran dalam Rukun Negara, tentunya sekolah-sekolah vernakular ini mempunyai potensi dalam membentuk aspirasi bersama dalam membentuk asas budaya perkongsian nilai-nilai kenegaraan Malaysia (Tan, 2010).

Pluralisme bangsa atau etnik, bukan merupakan satu ancaman dalam konteks perpaduan dan peneguhan jati diri, disebabkan negara umumnya dibentuk berasaskan dokumen kontrak sosial yang jelas dan telah menjadi subjek penerimaan umum dalam kalangan kesemua bangsa dan etnik. Persoalan utama yang menjadi jejasan kepada perpaduan bangsa adalah pelanggaran secara mutlak terhadap fasal-fasal yang diperuntukkan dalam Perlembagaan Negara (Embong 2007; Ahmad 2016).

Apa yang perlu diberikan perhatian dalam konteks untuk meletakkan sekolah-sekolah vernakular Jenis Kebangsaan Tamil dan Jenis Kebangsaan Cina ini, selari dengan aspirasi yang dihasrat untuk membina jati negara adalah dengan menjadikan pengajaran bahasa Melayu dalam bentuk kedudukannya sebagai bahasa kebangsaan, yakni menjadikan status pengajaran bahasa Melayu menyamai status yang dilaksanakan di sekolah-sekolah kebangsaan. Keadaan ini secara tidak langsung akan menjadikan falsafah disebalik pengajaran bahasa Melayu itu akan lebih berfokus ke arah membentuk nilai bersamaan dalam konteks penzahiran aspirasi nasional (Ahmad, 2016).

Usaha ke arah perpaduan nasional dan mengurangkan darjah polarisasi kaum perlu dianalisis dalam konteks pelbagai dimensi tindakan dan tingkah laku politik dan pemikiran sosial, juga berkait dengan realiti jurang ekonomi. Soal yang berkait dengan kewujudan sekolah satu aliran sebagai alternatif kepada usaha memperkukuh perpaduan nasional, secara khusus tidak begitu signifikan, terdapat beberapa unsur yang bersifat mikro dan makro perlu diberikan tumpuan serius.

Hal ini berkait rapat dengan pelaksanaan dasar, sokongan perundangan dan juga tindakan mobilisasi minda, perspektif serta persepsi masyarakat untuk menerima akan hakikat realiti perbezaan budaya antara kaum, pada masa yang sama memberikan fokus kepada keperluan menerima unsur pemersatu, dalam konteks penerimaan prinsip untuk hidup bersama dalam satu lingkungan sosial geografi, berteraskan Perlembagaan negara.

\section{KERANGKA DASAR IDENTITI NASIONAL}

Tindakan ke arah membina lingkungan sosio-politik-budaya untuk membentuk keterikatan terhadap nilai dan norma masyarakat, telah pun dilaksana bermula secara aktif pada tahun 1971, melalui kongres kebudayaan nasional. Kongres yang dianjur khusus untuk membentuk kerangka budaya yang dapat mendefinisi pola rupa bentuk masyarakat Malaysia, sebagai asas membina kebersamaan bagi mewujudkan perpaduan nasional.

Kongres ini boleh dianggap sebagai satu landasan untuk mereka bentuk kerangka budaya masyarakat Malaysia. Resolusi kongres tersebut memacak tiga asas utama (Yusof, 1985):

a. Islam menjadi unsur yang penting dalam pembentukan Kebudayaan Kebangsaan.

b. Kebudayaan kebangsaan hendaklah berteraskan kebudayaan rakyat asal rantau ini. 
c. Unsur-unsur kebudayaan lain yang sesuai dan wajar boleh diterima menjadi unsur kebudayaan Kebangsaan.

Bererti, asas kepada pengukuhan perpaduan nasional itu telah pun direncanakan, namun selepas hampir 44 tahun berlalu, kewujudan resolusi ini serta penerapan ke dalam aktiviti masyarakat masih tidak keruan. Pemikiran masyarakat masih terbelah dalam lingkungan kelompok kaum, masih terperangkap dalam konflik kepentingan dan kelangsungan bangsa Melayu, Cina dan India (Embong, 2007; Razak, 2009).

Pemikiran ke arah membina kesatuan fikiran sebagai bangsa Malaysia agak jauh tersasar. Jurang pemikiran sosial dan budaya dalam satu kesatuan Malaysia masih tetap menjadi isu yang sering menjadi konflik kepentingan. Tahap penerimaan terhadap konsep dan struktur budaya kebangsaan masih belum mengakar dalam masyarakat, konflik penerimaan masih berlaku, khsusus dalam kalangan masyarakat etnik bukan Melayu (Kheng, 2007; David, 2010).

Apa yang lebih penting, pihak berkuasa juga gagal untuk membentuk realiti tindakan yang berlambangkan jati diri bangsa. Salah satu aspek terpenting yang menjadi tunjang kepada pembentukan perpaduan dan jati diri bangsa adalah penzahiran kedudukan peranan penting bahasa Melayu, seharusnya penggunaan bahasa Melayu, bukan sahaja bersifat statik dalam sistuasi-situasi tertentu sahaja, sebaliknya berasaskan kedudukan serta pengiktirafan di sisi Perlembagaan Negara (Zubir, 2012; Ahmad, 2016; Tan, 2010).

Maka sewajarnya kedudukan bahasa Melayu dalam aspek penggunaannya sepatutnya diyakini tidak terancam dan menjadi keutamaan dalam semua sektor sama ada sekor kerajaan atau sektor swasta. Berdasarkan situasi ini maka tentunya akan memperkuat nilai bahasa Melayu sebagai bahasa kebangsaan (Zubir, 2015).

Mekipun pada masa yang sama kerangka tunjang kepada perpaduan nasional telah pun dipancang dengan kukuh melalui peruntukan Perlembagaan negara, khususnya sepanjang isu berkaitan identiti bangsa, reka bentuk hubungan sosial sebagaimana dinyatakan dalam perkara 3, berkaitan Islam sebagai agama Persekutuan, pada masa yang sama mengiktiraf kewujudan dan amalan agama-agama lain, yakni menetapkan asas bahawa negara bangsa Malaysia adalah dibina berasaskan kekuatan agama, bagaimana pun Islam dijadikan tunjang kepada dasar beragama itu memandangkan ia merupakan agama majoriti rakyat

Pemahaman perkara ini sudah cukup untuk memantapkan akan proses perpaduan nasional. Soal kekuatan agama dalam konteks dasar asas untuk memperkukuh perpaduan nasional, dipertegaskan lagi melalui prinsip rukun negara, "Kepercayaan kepada Tuhan", sepatutnya sudah menjadi peneguh kepada perpaduan nasional, sebaliknya realiti yang berlaku, terdapat unsur curiga dalam konteks amalan keagamaan, pemahaman antara agama tidak begitu diberikan penekanan.

Pemimpin badan Islam khususnya tidak begitu memperlihat usaha yang konkrit dalam menonjolkan sikap dan penyelesaian Islam dalam konteks hubungan antara kaum dan hubungan antara agama. Polarisasi agama juga menjadi unsur yang merenggan usaha perpaduan nasional (Ahmad, 2012; Sabri, 2014).

Bermakna jurang perpaduan nasional bukan dibina atas satu faktor, sebaliknya ia berkait rapat dengan komitmen pelaksanaan dasar, tingkah laku politik dan pola pemikiran sosial. Satu unsur penting dalam konteks pembinaan negara bangsa serta pengukuhan jati diri bangsa adalah 
bahasa kebangsaan. Perkara 152 Perlembagaan negara telah pun dengan jelas memperuntukkan akan peranan bahasa Melayu sebagai bahasa kebangsaan (Hussin, 2008).

Ini bermakna bahasa Melayu itu berfungsi sebagai bahasa penyatu dan bertindak sebagai tonggak identiti nasional, penggunaan bahasa Melayu tertakluk kepada segala urusan, khususnya ditafsirkan dalam konteks urusan rasmi. Namun, walau pun diperundangkan, kadudukan bahasa Melayu sebagai bahasa kebangsaan, bahasa rasmi negara masih tidak terserlah akan fungsinya secara nyata (Hassan, 2015; Ahmad, 2016).

\section{Bahasa Melayu dalam Realiti Pendidikan Negara}

Ketidak pedulian terhadap bahasa Melayu sebagai bahasa kebangsaan, bahasa rasmi negara, merupakan antara faktor yang menjadi ancaman kepada perpaduan nasional, bukan sahaja atas sifatnya sebagai bahasa perhubungan antara rakyat, sebaliknya juga sebagai bahasa diplomatik dan bahasa perniagaan dan bahasa yang mengungkap tradisi keilmuan. Maknanya, wujudnya krisis keyakinan terhadap bahasa Melayu, meski pun telah diperundangkan dalam Perlembagaan negara merupakan faktor yang menjarakkan perpaduan nasional (Hassan Ahmad, 2016; Abdullah Hassan, 2015).

Tambahan pula, sektor swasta secara jelas menafikan akan kepentingan penggunaan bahasa Melayu dalam setiap urusan niaga dan komunikasi. Sekali gus merendahkan kedududukan serta fungsi bahasa Melayu dalam konteks pembinaan negara. Secara tidak langsung memudarkan keyakinan masyarakat terhadap kesesuaian serta kesepadanan bahasa Melayu sebagai bahasa interaksi dan pembina wacana bangsa. Realiti ini akan menyebabkan jarak antara kaum akan lebih melebar (Ahmad, 2016; Hassan, 2015).

Isu yang dikaitkan dengan sekolah-sekolah vernakular Jenis Kebangsaan Cina dan Tamil, secara umum bukanlah merupakan pengancam mutlak kepada perpaduan nasional. Memandangkan sekolah-sekolah vernakular ini wujud pada peringkat dasar, tahun 1 hingga tahun 6, proses sebenar pengukuhan perpaduan nasional itu, hakikatnya perlu direka bentuk secara lebih berkesan pada peringkat pendidikan menengah dan selanjutnya peringkat pendidikan tinggi (Hussin, 2008; Sua, 2009; Tan, 2010).

Dasar Pendidikan Kebangsaan sebegaimana terkandung di dalam Akta Pendidikan 1996 perlu direalisasi dengan penuh ketegasan untuk membina keyakinan masyarakat terhadap keupyaan sistem pendidikan untuk berperanan dalam membina proses sosialisasi bangsa (Arshad, 2007).

Peruntukan dalam Akta Pendidikan 1996 perlu dilaksana secara konkrit, khususnya berkaitan Perkara 74 yang menyentuh soal keperluan institusi pendidikan swasta untuk mematuhi keperluan penggunaan Kurikulum Kebangsaan dalam pelaksanaan proses pendidikan. Apa yang lebih penting, perkara 17(1) perlu dikuatkuasakan sepenuhnya dan tidak sepatutnya Menteri menggunakan peruntukan kuasa sebagaimana yang diberikan dibawah perkara 17(1) ini daripada mengecuali pematuhan untuk pemakaian kepada mana-mana institusi pendidikan swasta yang ditubuhkan.

Isu berkaitan bahasa Melayu, sebagaimana yang dilembagakan melalui Akta Bahasa Kebangsaan 1967 dan peruntukan Perlembagaan Perkara 152 perlu dilihat sebagai yang utama penting dalam mempertahankan wibawa negara, khususnya dalam usaha memperkukuhkan perpaduan bangsa. 
Pihak berkuasa juga seharusnya mempunyai pemikiran dan tindakan yang tegas serta konkrit berkaitan dengan usaha pemartabatan bahasa Melayu, khususnya dalam sektor pendidikan swasta. Apabila sesuatu itu telah diperundangkan, sewajarnya ia dipastikan akan kuat kuasa pelaksanaan secara konkrit, ini merupakan isu pokok dalam konteks untuk mempertahankan jati diri serta memperkukuh persefahaman antara kumpulan bangsa (Hussin, 2008; Kementerian Pendidikan Malaysia, 2013; Ahmad, 2016).

\section{Liberalisme Bahasa Pendidikan Swasta}

Berdasarkan Akta Institusi Pendidikan Swasta 1996, juga dengan jelas telah memperuntukkan status bahasa Melayu sebagai bahasa pengantar, sebagaimana yang dinyatakan dalam perkara 41(1). Bagaimanapun peruntukkan bukanlah merupakan satu peruntukkan yang konkrit, sebaliknya ia tidak menggambarkan komitmen yang kuat untuk memartbatkan kedudukan bahasa Melayu, terutamanya dalam realiti pendidikan swasta.

Kedudukan bahasa Melayu dalam konteks Akta Insititusi Pendidikan Swasta 1996, hakikatnya bukan merupakan sesuatu yang kuat dan mantap, sebaliknya ia bersifat formaliti sahaja dan tidak mempunyai apa-apa makna dalam konteks memperteguh penggunaan bahasa Melayu sebagai bahasa pengantar dalam pendidikan sektor swasta.

Peruntukan Perkara 41(1), hakikatnya merupakan satu peruntukan yang lemah tidak bersifat mendasar dalam konteks penanaman roh ke arah usaha tegas yang bermakna ke arah menjadikan bahasa Melayu sebagai wahana yang benar-benar berfungsi menguasai dunia akademik. Kuasa Menteri seharusnya digunakan secara berkesan untuk mempertahan penggunaan meluas bahasa Melayu dalam dunia akademik, sebagai menyahut peruntukan Perkara 41(1), namun demikian, realiti yang wujud memperlihatkan secara tidak langsung kuasa Menteri menjadi faktor pelemah kepada usaha memantap serta memartabat bahasa Melayu, khususnya dalam konteks sektor pendidikan swasta.

Perkara 41(1) yang tertera dalam Akta Institusi Pendidikan Swasta 1996, hakikatnya tidak mempunyai nilai yang signifikan, kerana ia secara tidak langsung boleh dinafikan melalui peruntukan 41(3), antara lain memberi kuasa penuh kepada menteri untuk meluluskan penggunaan bahasa pengantar di Institusi Pengajian Tinggi, selain daripada bahasa Melayu. Dinyakatakan, "Walau apa pun subsksyen (1), institusi pendidikan tinggi swasta boleh, dengan kelulusan Menteri a) mengendalikan suatu kursus pengajian atau sebahagaian yang substantial suatu kursus pengajian dalam bahasa Inggeris".

Walaupun Akta Institusi Pendidikan Swasta 1996, melalui peruntukan Perkara 42(1) yang memberikan kuasa kepada Menteri untuk mengarah institusi pendidikan swasta, menggunakan bahasa Melayu dalam pengendalian kursus pengajian, setelah pengecualian diberikan berdasarkan Perkara 41(1), namun realitinya ia hanyalah merupakan semata-mata peruntukan yang diadakan, hakikat pelaksanaannya, bukanlah merupakan keutamaan.

Hakikat ini terbukti, berdasarkan sejumlah lebih kurang 496 institusi pendidikan swasta yang berdaftar, hampir kesemuanya menggunakan bahasa pengantar adalah bahasa selain daripada bahasa Melayu dan majoritinya menggunakan bahasa Inggeris sebagai bahasa pengantar (Jambi, 2008; Peng, 2008; Hassan, 2015).

Secara khususnya Perkara 42(1) menjelaskan, "Berkenaan dengan kelulusan yang diberikan oleh Menteri di bawah perenggan 41(3) (a) Menteri boleh pada bila-bila masa selepas itu 
mengarah supaya bahasa kebangsaan digunakan untuk mengendalikan kursus pengajian tersebut. Bermakna sehingga kini, peruntukan ini tidak pernah digunakan oleh Menteri dalam konteks untuk memperluaskan penggunaan bahasa Melayu di institusi pendidikan swasta.

Pemecahan bahasa dalam konteks pengingkaran terhadap dasar bahasa, dalam konteks pelaksanaan proses pendidikan peringkat menengah dan pendidikan tinggi, merupakan unsur yang menjadi pengancam kepada perpaduan nasional. Jiwa bangsa hakikatnya terikat dengan bahasa yang menjadi bahasa nasional, bahasa kebangsaan, memandangkan ia secara tidak langsung berfungsi sebagai peneguh identiti nasional (Ahmad, 2016).

Lantas ia menjadi pengikat yang kuat untuk menumbuhkan perasaan kesatuan dan perpaduan nasional. Ini bererti bahasa Melayu perlu diperkukuhkan asas serta pelebaran tapak untuk berfungsi secara dinamik dalam kerangka pendidikan menengah dan pendidikan pada peringkat pengajian tingggi, tanpa pengecualian sama ada pendidikan sektor awam atau sektor swasta (Razak, 2009; Ahmad, 2016).

Maka pelaksanaan secara menyeluruh dan tegas Akta pendidikan 1996 dan Akta Institusi Pendidikan Swasta 1996, merupakan sesuatu yang amat penting kerana ia akan memberikan keyakinan terhadap peranan serta wibawa bahasa Melayu dalam konteks nilai kebergunaan. Tindakan yang bersifat reaktif terhadap bahasa Melayu akan menyebabkan wujudnya sentimen manipulatif dan jejasan terhadap nilai penggunaannya dalam kalangan masyarakat (Hassan, 2015).

\section{Pendidikan Pelebaran Jurang Perpaduan}

Penyebaran unsur yang mengancam status quo bahasa Melayu, khususnya dalam konteks seumpama PPSMI dan terkini usaha Kementerian Pendidikan memperkenal DLP (Dual Language Programme) itulah sebenarnya yang menjadi pengancam kepada perpaduan nasional, disebabkan secara tidak langsung wujudnya situasi manipulasi sentimen untuk memperkecilkan kedudukan bahasa Melayu, secara tidak langsung akan melebarkan jurang pemikiran dan corak berfikir dalam kalangan rakyat (Hassan, 2007 \& 2015).

Peneguhan hakikatnya perlu diberikan dalam membentuk dan membina reka bentuk pendidikan peringkat menengah dan pengajian tinggi, realiti pada dua peringkat pendidikan inilah yang menjadi pemangkin kepada keberkesanan asas perpaduan nasional (Sufean Hussin, 2008), memandangkan apa pun aliran bahasa yang digunakan pada peringkat rendah (sama ada bahasa Cina atau bahasa Tamil), namun pada pendidikan peringkat menengah tercantum dalam satu bahasa pengantar iaitu bahasa Melayu, sebagaimana yang dinyatakan dalam Akta Pendidikan 1996.

Keadaan ini menjadikan pendidikan peringkat menengah itu merupakan satu wahana yang cukup penting untuk memperkukuh kekuatan perpaduan nasional. Kekacauan proses pendidikan pada peringkat menengah akan menjadi kekacauan kepada penyuburan perasaan perpaduan nasional (Arshad, 2007; Hussin, 2008; David, 2010).

Sikap liberal terhadap bahasa pengantar pendidikan pada peringkat menengah dan pengajian tinggi, bukan sahaja melebarkan jurang pemikiran antara pelajar, bahkan juga akan menjadi krisis pemikiran dalam kalangan masyarakat terhadap wibawa serta kedudukan bahasa Melayu sebagaimana yang dinyatakan dalam fasal 152, peruntukan 17 Akta Pendidikan 1996, Akta Institusi Pendidikan Swasta 1996 dan Akta Bahasa Kebangsaan 1967. 
Realiti ini menjadikan masyarakat akan berdepan dengan krisis identiti serta selimpangan budaya dan menajamkan perbezaan antara kaum, situasi ini hakikatnya adalah lebih serius, berbanding dengan kewujudan sekolah-sekolah vernakular Cina dan Tamil, pada peringkat pendidikan rendah. Kemunculan sekolah-sekolah vernakular Cina dan Tamil ini, hakikatnya telah didiiktiraf sebagai sebahagian daripada sistem pendidikan kebangsaan sebagaimana yang digariskan dalam perkara 28 Akta Pendidikan 1996.

Proses politik dalam usaha perluasan pengaruh dominasi politik, merupakan antara penyumbang yang menjejaskan usaha ke arah perpaduan nasional. Tindakan pihak-pihak tertentu yang membangkit serta mengungkit "perihal kaum pendatang", walau pun sudah hampir melepasi 59 tahun merdeka, secara tidak langsung akan tersebarnya pergeseran sentimen yang membuahkan hilangan kepercayaan antara kaum.

Membangkit serta memperbesarkan peristiwa 13 Mei 1969, biarpun telah 46 tahun berlalu, atas kepentingan pengaruh politik, menjadikan pemikiran rakyat secara bereterusan dikepung dengan pemikiran perkauman. 13 Mei dijadikan agenda "peras ugut" untuk mendapat sokongan politik. Satu tingkah laku politik yang tersasar. Emosi membuak kononnya tentang ketuanan Melayu, perjuangan martabat Melayu tanpa berjejak realiti demografi politik, merupakan antara unsur yang boleh menjarakkan jurang bagi membina kekukuhan asas perpaduan nasional (Soong, 2008; Ibrahim, 2015).

\section{RUMUSAN DAN KESIMPULAN}

Sikap politik yang digerak di luar lingkungan moral dan pertembungan idelogi politik, membangkitkan tuntutan-tuntutan kaum yang disifatkan sebagai bersalahan dengan semangat Perlembagaan atau konvensyen kemerdekaan, merupakan antara faktor penyumbang kepada penajaman sentimen perkauman (Razak, 2009; David, 2010).

Dalam perebutan pengaruh, ahli-ahli politik sama ada di pihak parti pemerintah atau pun parti pembangkang, merupakan antara pencetus kepada letusan rasa perkauman. Sifat politik mengapikan ancaman dan membina suasana terancam khususnya dalam kalangan masyarakat Melayu, menjadikan minda Melayu terbentuk dengan pola pemikiran tahap kecurigaan tertinggi terhadap kaum-kaum lain, khususnya masyarakat Cina dan India (Kheng, 2007).

Soal yang berkaitan dengan pembentukan perpaduan, pengukuhan jati diri bangsa dan penerimaan aspirasi bersama, bukan secara mutlak tertanggung dalam konteks proses pendidikan. Unsur-unsur sosial dan proses politik merupakan antara faktor yang menjadi dimensi penentu kepada tahap kecenderungan pengukuhan perpaduan serta kekuatan ikatan terhadap unsur jati diri (Toti, 2014).

Pertembungan kepentingan sosial, khususnya usaha untuk mempertahan sifat bangsa dan etnik merupakan antara isu yang melebarkan jurang perpaduan, tambahan pula keupayaan penguasaan ekonomi yang memperlihatkan dominasi kaum tertentu, merupakan antara faktor yang menimbulkan kecurigaan antara kaum. Ini bermakna tujuan di sebalik pelaksanaan Dasar Ekonomi Baru yang berfokus untuk menyeimbang jurang ekonomi, penekanan terhadap pemilikan ekuiti 30 peratus dalam kalangan Bumiputera, hakikatnya tidak kesampaian (Ghazali, 1990).

Persoalan dalam membangunkan pemikiran perpaduan dan memperkasa jati diri bangsa, bukan semata-mata terikat dengan realiti proses pendidikan. Tingkah laku sosial masyarakat serta 
usaha mempertahankan kepentingan politik kelompok, berdasarkan idealisme politik sukuan, merupakan antara unsur utama yang boleh mencetuskan pemisahan masyarakat (Embong, 2007; Low, 2000; David, 2010).

Tindakan perjuangan idealisme yang bercorak pengelompokan etnik dan kepentingan keagamaan, merupakan antara aspek yang menajamkan konflik serta polemik yang berterusan. Keadaan ini tentunya akan menjejaskan pemikiran sosial serta kelakuan sosial yang cenderung untuk mempertahankan kepentingan kepercayaan masing-masing (Razak, 2009; Othman, 2012)

Hakikatnya, ketidak patuhan terhadap peruntukan perlembagaan, khususnya dalam proses pembuatan dasar dan pelaksanaan dasar akan membuka ruang kepada konflik kepentingan. Peruntukan perlembagaan sewajarnya dijadikan asas kepada pembinaan perpaduan dan jati diri bangsa (Hussin, 2008; Hassan, 2015).

Kepentingan politik serta politik demokrasi merupakan antara unsur di luar proses pendidikan yang menjadi unsur kepada tercetusnya konflik sosial. Perjuangan politik yang di dorong oleh pertembungan pemikiran serta sikap curang dalam tanggungjawab politik khususnya pelanggaran terhadap integriti moral, menjadi antara fakor yang mengancam usaha untuk membina perpaduan (Kheng, 2007; Othman, 2015). Bermakna matlamat pendidikan sebagaimana dinyatakan melalui dasar pendidikan kebangsaan tidak akan mencapai piawai pelaksanaan (Hussin, 2008; Sabri, 2014).

Ketajaman konflik politik yang membawa kepada polemik dan berdebatan terbuka berkait dengan sesuatu isu, terutamanya sepanjang yang berkaitan dengan kuasa dan kekuasaan secara tidak langsung akan membuka ruang kepada wujudnya politik perkauman. Hal ini disebabkan ruang politik Malaysia, meski pun pada abad yang ke-21, masih berorientasikan politik kaum dan keagamaan (Low, 2000; Amer, 2011; Mat Jali, 2012; Sabri, 2014).

Pembinaan asas perpaduan sebenarnya telah dizahirkan secara tuntas berasaskan kepada perundangan dan peraturan yang telah ditetapkan, kontrak sosial telah meletakkan bahasa Melayu sebagai bahasa kebangsaan, penerimaan semua bangsa sebagai satu warga negara, sistem pendidikan dengan kandungan kurikulum yang seragam serta sistem pembahagian kuasa dalam pentadbiran negara, merupakan unsur-unsur yang sewajarnya menjadi pemangkin kepada perpaduan negara (Arshad, 2007; Jamaluddin, 2011).

Proses pendidikan merupakan unsur yang mendorong kepada pembinaan sosiolisasi yang bersifat terhad dalam dimensi berfokus dalam lingkungan waktu serta persekitaran yang terbatas. Dengan perkataan lain, proses pendidikan bukan sesuatu yang bersifat mutlak untuk mempengaruhi pembinaan serta pertumbuhan pemikiran yang berfokuskan perpaduan dan bertunjang jati diri bangsa (Razak, 2009; Othman, 2012).

Faktor diluar proses pendidikan, tingkah laku umum masyarakat serta bentuk polemik sosial yang diwujudkan oleh pihak-pihak berkepentingan menjadi antara dimensi yang mempengaruhi pola pemikiran terhadap sentimen perpaduan serta penonjolan jati diri bangsa (Sabri, 2014).

Proses pendidikan, sememangnya merupakan realiti yang subur untuk menanamkan doktrin kesatuan bangsa, namun atas sifatnya berkelompok secara mikro, maka usaha tersebut perlu juga mendapat dokongan dan sokongan yang kuat daripada pelaksanaan dasar-dasar kerajaan 
agar selaras dengan hasrat yang terkandung dalam perlembagaan negara (Arshad, 2007: Kheng, 2007).

Apa yang nyata, pemikiran masyarakat perlu dibentuk secara berstrukur, bagi mewujudkan sentimen penerimaan terhadap budaya teras Malaysia. Berdasarkan Perlembagaan Negara, maka budaya teras Malaysia itu adalah bersumberkan kepada falsafah pemikiran tradisi kebumiputeraan, yakni selaras dengan apayang diperakui dalam Dasar Kebudayaan Kebangsaan serta idelaisme yang tercatat dalam kandungan Rukun Negara (Embong, 2007; Ahmad, 2016).

Berdasarkan hakikat ini, tingkah laku hubungan antara etnik yang bersifat makro, merentasi aktiviti sosial dan pemikiran politik perlu disandarkan kepada budaya teras yang diperakui. Pertentangan politik dalam konteks prinsip demokrasi, seharusnya bersifat ideologi serta pemahaman dalam realiti mempetahankan integriti daripada berlakunya penyalah gunaan kuasa dalam konteks melahirkan tindakan politik yang bersifat korupsi dan berkepentingan diri. Hakikatnya landaan politik sebegini, mempunyai kecenderungan dalam merosakkan perpaduan serta jati diri bangsa.

Proses pendidikan yang berlangsung dalam persekitaran sosial berkonflik antara kepentingan budaya serta amalan politik yang diluar batas integriti, sebenarnya tidak begitu berkecendeungan untuk membentuk sikap, pemikiran, tingkah laku dan idealisme yang menjurus kepada wujudnya peningkatan sentimen emosi terhadap perpaduan, juga merangsang kepada pertumbuhan kepada pembinaan jati diri bangsa.

\section{RUJUKAN}

Abdul Aziz, H., \& Mansor, N. (2013). Persepsi tenaga akademik di institusi pengajian tinggi terhadap kemampuan bahasa Melayu berfungsi sebagai bahasa pengantar utama Ilmu. Jurnal Pendidikan Bahasa Melayu, 41-48.

Ahmad M. I., Stapa, Z., Othman, M., \& Yaacob, M. (2012). Islam dalam pendidikan dan hubungannya dengan pembentukan jati diri bangsa Melayu di Malaysia. Jurnal Hadhari Special Edition, 37-50.

Hassan, A. (2016). Bahasa dan Pemikiran Melayu. Kuala Lumpur: Dewan Bahasa dan Pustaka.

Amer, S., Mohammad Redzuan, O., Zulkarnain, A., \& Rosmadi, F. (2011). Politik etnik Malaysia: analisis pasca pilihan raya umum ke-12 mengenai sokongan bukan Melayu kepada UMNO dan PAS. Malaysia Journal of Society and Space, 18-27.

Arshad, A. R. (2007). Unity and education in Malaysia. Kuala Lumpur: Dewan Bahasa dan Pustaka.

Bernama. (2017, February 27). Free Malaysia Today. Retrieved from http://www.freemalaysiatoday.com:

http://www.freemalaysiatoday.com/category/bahasa/2017/02/27/kerajaan-salur-rm565-jutakepada-sekolah-cina-sejak-2009/

Bohari, H. (2015). Dasar ekonomi baru: kesan sosio ekonomi di daerah Manjung Perak. Pulau Pinang: Universiti Sains Malaysia.

Cheween, L. (2015, January 9). The Rakyat Post. Retrieved from http://bm.therakyatpost.com: http://bm.therakyatpost.com/berita/2015/01/09/tambah-bilangan-pelajar-bukan-cina-di-sekolahcina/

David, M. K., McLellan, J., Meng, N. Y., Le, L. M., \& Tien, E. Y. (2010). Ethnic relations and nation building: the way forward. Petaling Jaya: Strategic Information and Research Development Centre.

Embong, A. R. (2004). Globalisation culture \& inequalities. Kuala Lumpur: Penerbit UKM.

Embong, A. R. (2007). Rethinking ethnicity \& nation bulding: Malaysia, Sri Lanka \& Fiji in comparative perspective. Kajang: Persatuan Sains Sosial Malaysia. 
Hassan, A. (2007). Mengapa kami bantah penggunaan bahasa Inggeris dalam mengajarkan Sains dan Matematik. Kuala Lumpur: Persatuan Penterjemah Malaysia.

Hassan, A., \& Borhan, Z. A. (2015). Kami Bantah DLP. Kuala Lumpur: PTS Akademia.

Sufean, H. (2008). Pendidikan di Malaysia: sejarah, sistem dan falsafah. Kuala Lumpur: Dewan Bahasa dan Pustaka.

Ibrahim, A. R. (2015). 13 Mei 1969 di Kuala Lumpur. Kuala Lumpur: Dewan Bahasa dan Pustaka.

Jamaluddin, M. K. (2011, April 1). Sosio Humanika. Retrieved from http://www.academia.edu: http://www.academia.edu/1803174/Sistem_Pendidikan_di_Malaysia_Dasar_Cabaran_dan_Pelaks anaan_ke_Arah_Perpaduan_Nasional

Jambi, J. (2008). Cabaran dan proses pemantapan Bahasa Melayu. Jurnal Pengajian Melayu, 68-90.

Kementerian Pendidikan Malaysia. (2013). Pelan Pembangunan Pendidikan Malaysia 2013-2015. Kuala Lumpur: Kementerian Pendidikan Malaysia.

Kerajaan Malaysia. (2014). Akta Pendidikan 1996 (Akta 550). Kuala Lumpur: International Law Service.

Kerajaan Malaysia. (2014). Akta Pendidikan Tinggi Swasta 1996. Kuala Lumpur: International Law Books Services.

Kheng, C. B. (2007). Malaysia: envisioning the nation at the time of independence. Dlm. A. R. Embong, Rethinking Ethnicity \& Nation-Building: Malaysia, Sri Lanka \& Fiji in Comparative Perspective (pp. 40-56). Kuala Lumpur: Persatuan Sains Sosial Malaysia.

Low, Y. (2000). Pola politik Cina di Semenanjung dalam tahun 1990an. Serdang: Universiti Putera Malaysia.

Malaysia, Kerajaan Malaysia. (2014). Perlembagaan Persekutuan Malaysia. Kuala Lumpur: International Law Book Services.

Mat Jali, M., Besar, J., Sidek, A., Ibrahim, Y., Nor Aziah, M., \& Ismail, K. (2012). Politik pembangunan dalam pilihan raya kecil Dewan Undangan Negeri Batang Air, Sarawak. Malaysia Journal of Society and Space, 88-97.

Mohd Ghazali, M. Z. (1990). Dasar ekonomi baru: kelemahan dan penyelewengan. Skudai: Universiti Teknologi Malaysia.

Othman, M. Y., Dakir, J., Samian, A. L., Hashim, M. S., Awal, N. A., Yahya, S. A., Bakar, M. A. (2012). Jati diri kebangsaan dalam kalangan pelajar institusi pengajian tinggi. Jurnal Hadhari, 6778.

Othman, S., Sabil, A. M., \& Lateh, G. (2015). Pemikiran akal budi dan sosiobudaya Melayu dalam pendidikan. International Journal of Education and Training, 1-10.

Peng, C. F. (2008). Tahap penggunaan Bahasa Melayu dan Bahasa Inggeris dalam kalangan mahasiswa/i IPTA dan IPTS dalam sistem pendidikan negara. Jurnal Pengajian Melayu, 16-36.

Razak, M. R. (2009). Pembinaan negara bangsa: peranan pendidikan sejarah dan dasar pendidikan kebangsaan. JEBAT, 90-106.

Sabri, A. Z., Abu, R., \& Hamzah, N. H. (2014). Religion, ethnicity and national identity: an analysis of the Islamic experience in a multi-ethnicand multi-religious Malaysian society. The International Asian Research Journal , 51-62.

Soong, K. K. (2008). 13 Mei Dokumen-dokumen deklasifikasi tentang Rusuhan 1969 Malaysia. Petaling Jaya: Suaram Komunikasi.

Sua, T. Y. (2009). Perkembangan pendidikan di Malaysia: peranan Lim Lian Geok dan Aminuddin Baki. Jurnal Alam dan Tamadun Melayu, 139-166.

Tan, Y. S. (2010). Isu bahasa, etnik dan pembinaan negara bangsa dalam sistem pendidikan. Pulau Pinang: Penerbit Universiti Sains Malaysia.

Toti, Z., Amir, R., \& Rahman, S. (2014). Pembinaan instrument jati diri pelajar sekolah menengah di Malaysia. Social Sciences Research (pp. 664-672). Kota Kinabalu: World Conference net.

Yusof, W. A., \& Borhan, Z. A. (1985). Ideologi dan kebudayaan kebangsaan. Kuala Lumpur: Jabatan Pengajian Melayu Universiti Malaya.

Zubir, Z., Rahim, N. A., Zulkifli, N. S., \& Yusuf, W. S. (2012). Globalisasi, Bahasa Melayu dalam Arus globalisasi: keutuhan jati diri dan kekuatan budaya Melayu. Journal of Human Development and Communication, 129-135. 